\title{
FLOODPLAIN FORMS ALONG THE LOWLAND MAROS RIVER, HUNGARY
}

\section{Márton Balogh ${ }^{1}$ (D) Tímea Kiss ${ }^{1}$ (D) Károly Fiala ${ }^{2}$ - István Fehé- rváry $^{2}$}

${ }^{1}$ Department of Physical Geography and Geoinformatics

University of Szeged

Egyetem u. 2-6, 6722, Szeged: Hungary

e-mail: baloghmarton.geo@gmail.com (corresponding author)

${ }^{2}$ Lower Tisza District Water Directorate

Stefánia 4, 6720, Szeged: Hungary

\begin{abstract}
The floodplain forms of lowland rivers act as fluvial archives, as their morphology, material and spatial characteristics refer to the hydromorphological changes of the river and (dis)connectivity of the alluvial system. The aims of the research are (1) to identify natural levees, crevasses, and point-bars on the Hungarian floodplain section of the Maros River, (2) to measure their morphometric parameters, and (3) to analyse their spatial and temporal variations in connection with various human impacts. Six genetic types of natural levees and pointbar systems developed as the result of various human impacts, thus the development of the forms terminated or became laterally limited.
\end{abstract}

\section{Key words}

natural levee $\bullet$ crevasse $\bullet$ point-bar $\bullet$ human impact $\bullet$ LiDAR survey $\bullet$ Maros River $\bullet$ Hungarian floodplain

\section{Introduction}

Floodplain forms are dominantly the result of fluvial processes, and they play a key role in the water and sediment budget of river systems. They could influence the height of floods by controlling the hydraulic conductivity of the floodplain (Zwoliński, 1992; Gomez, Phillips, Magilligan, \& James, 1997; Asselman \& Middelkoop, 1998; Schweitzer, Nagy, \& Alföldi, 2002). Two main processes contribute to the evolution of floodplain forms: lateral and vertical accretion. The comparative intensity of these processes is primarily determined by stream power and sediment transport (Nanson, 1986; Brierley \& Hickin, 1992, Zwoliński, 1992). The lateral accretion mainly connected to lateral channel shift (Nanson \& Croke, 1992), or to channel narrowing caused by decreasing discharge or sediment flux (Kiss \& Blanka, 2012). Vertical accretion is connected to floods (Wolfert, 
Hommel, Prins, \& Stam, 2002), when usually coarse grains accumulate along the banks forming natural levees (Asselman \& Middelkoop, 1998; Kiss, Sándor, \& Gresó, 2004; Sándor, 2011), while fine grains are deposited on the entire floodplain creating sediment sheets (Nanson \& Croke, 1992; Cazanacli \& Smith, 1998; Bridge, 2003; Kiss et al., 2004; Kiss, Oroszi, Sipos, Fiala, \& Benyhe, 2011).

Floodplains could be classified into three main groups based on their development and form assemblage (Brown, 1983). On wide floodplains the lateral channel migration is almost unlimited, thus lateral accretion plays an important role in the development of point-bars, swales, oxbow lakes, abandoned channel sections and sediment plugs. Meantime, on vertically accreting floodplains natural levees, crevasses, sand or gravel splays, and backswamps develop. The sedimentation of oxbow lakes, channel fragments and sediment plugs are also determined by vertical accretion (Happ, Rittenhouse, \& Dobson, 1940; Lóczy, 2013). On the floodplain of narrow valleys forms built of colluvial debris could also be apparent, though their lifetime is usually short due to their rapid erosion (Dietrich, Wilson, \& Reneau, 1986). The development of floodplain forms is greatly dependent on the hydrological characteristics of the river, as vertical accretion occurs during floods, while lateral accumulation could be continuous, independently of the water stage (Lóczy, 2013).

Natural levees are ribbon-like accumulational forms (Nanson \& Croke, 1992; Zwoliński, 1992; Branß, Dittrich, \& Núñez-González, 2016) adjacent to the concave (Fisk, 1947; Allen, 1965; Sándor, 2011; Radecki-Pawlik et al., 2016) or straight river banks (Brierley, Ferguson, \& Woolfe, 1997; Klasz et al., 2014). During floods the floodwave enters to the floodplain, its flow velocity decreases due to the increased friction caused by vegetation and the rapid drop of the water column, thus coarse grains are deposited, and the formation of a narrow and steep natural levee begins (Wolman \& Leopold, 1957; Wolfert et al., 2002). During high floods coarse grains are transported and deposited on top. Usually, the material of the natural levees is coarser than the sediments of the floodplain but finer than the bedload (Brierley et al., 1997). The further the sediments are transported from the bankline, the lower of the slope of the natural levee will be (Cazanacli \& Smith, 1998). Their size indicates the sediment transport characteristics of a river, and the medium-term (100$1000 \mathrm{y}$ ) changes of the flow regime (Hudson $\&$ Heitmuller, 2003). Due to the very dense vegetation and the construction of bank protection (revetment), quite high natural levees could develop (Sándor, 2011), increasing the bankfull level and stream power of floods, contributing to the development of devastating floods (Schweitzer et al., 2002).

Crevasses develop on natural levees, and during floods, they dissipate the energy of the flood wave diverting water towards the distal areas of the floodplain, whilst at falling stages, they drain water from the floodplain towards the channel (Smith \& Pérez-Arlucea, 2008). They can develop during bankfull stage, when the flood breaks through the loose material of the natural levee, thus a small crevasse channel develops (Gábris, Telbisz, Nagy, \& Belardinelli, 2002; Fryirs \& Brierley, 2012). As the flood enters to the floodplain through the crevasse, its velocity decreases, and it deposits the transported material (originating from the channel and also from the natural levee) in a form of fanshaped crevasse splay (Smith, Cross, Dufficy, \& Clough, 1989). Later the loose material of the crevasse splays could be reworked during floods by secondary crevasses, thus a whole crevasse system develops (Smith \& Pérez-Arlucea, 2008). During high floods, even along the crevasses natural levees could build up (Coleman, 1969).

In contrary to natural levees and crevasses, point-bars develop along concave banks of bends and meanders (Wolman \& Leopold, 1957). They stretch from the bottom of the channel to the bankline, thus sediment could be deposited at any stage (Lóczy, 2013). Usually, their grain-size is finer than of the natural 
levee on the opposite side of the channel, as the thalweg is located far from the concave bank (Bridge, 2003). As the result of lateral channel shift and lateral aggradation, point-bar systems could develop (Gábris et al., 2002), between them deeper-lying swales are formed, where fine-grained layers are deposited during floods (Allen, 1965; Schweitzer et al., 2002; Fryirs \& Brierly, 2012).

The horizontal extent of these floodplain forms can vary from metres to several kilometres, while their vertical parameters from centimetres to meters (Allen, 1965). Their size depends on the hydro-morphological characteristics of the river, as higher floods usually have higher flow velocity and increased sediment discharge, thus they can create larger forms (Brown, 1983; Chalov, 2004; KeenZebert et al., 2013). Their size also depends on the slope of the river (Fryirs \& Brierley, 2012), its discharge (Taylor, 2002; Sorrells, 2012), and the density of riparian vegetation (Steiger, Tabacchi, Dufour, Corenblit, \& Peiry, 2005). As direct or indirect human impact could influence these hydro-morphological parameters (Gregory, 2004), we supposed that the morphology of floodplain forms is also influenced by human impacts (Zwoliński, 1992).

As the dimensions of floodplain features are quite variable, their survey by classical topographical mapping is difficult with sufficient accuracy, besides the field survey of large floodplain areas could be laborious and time-consuming due to the dense vegetation. However, high-resolution LiDAR data allow scientists to obtain fast and accurate terrain measurements over large areas (Lane, Westaway, \& Hicks, 2003), and to identify fluvial forms. For example, Notebaert, Verstraeten, Govers, and Poesen (2009) analysed the spatial characteristics of floodplain forms, whilst Sagar (2013) made an attempt to create an automated delineation method of floodplains and floodplain forms, whereas Wierzbicki, Ostrowski, Mazgajski, \& Bujakowski (2013) measured the vertical accretion rate and its spatial differences.

Very intensive accumulation processes characterise the floodplain of the Maros
River (Kiss et al., 2011), which could be explained by its considerable sediment discharge. However, the processes of vertical and horizontal aggradation is limited by recent channel narrowing and incision (Blanka \& Kiss, 2006; Kiss, Nagy, \& Balogh, 2017; Kiss, Balogh, Fiala, \& Sipos, 2018). The spatial and temporal changes in accumulation are known from sedimentary analysis (Kiss et al., 2011), but the various floodplain forms created by the intensive accumulation were unknown due to the missing spatial data. However, a new LiDAR dataset provided an opportunity to identify and evaluate the floodplain forms created by vertical accretion on the floodplain of the $53.7 \mathrm{~km}$ long lower reach of the Maros.

The aims of this paper are (1) to identify the natural levees, crevasses and point-bars on the floodplain, (2) to measure their horizontal and vertical parameters, (3) to reveal their spatial characteristics, (4) and to evaluate their changes during the last ca. 150 years in connection with human impact.

\section{Study area}

The Hungarian section of the Maros floodplain was studied in detail, between Nagylak and Szeged (53.7 km). The Maros constitutes the border between Romania and Hungary along the upstream section (units 1-12), then it flows entirely in Hungary until its confluence with the Tisza River. Therefore, the LiDAR survey covers just the northern part of the floodplain along the upstream border section, whilst at downstream (units 13-31) both floodplain sides were analysed (Fig. 1.). The upstream floodplain section (units 1-8) is located on the alluvial fan of the river with high slope (0.00038), the next sections are the fan-front (units 9-11), and the secondary alluvial fan (units 12-20), therefore here the floodplain slope decreases to 0.00012 0.00022 . After leaving the alluvial fan the river flows across its natural floodplain (units 21-24) with a slope of 0.00005, whilst on the most downstream section (units 25-31) it drops to 0.00002 (Kiss et al., 2011). 


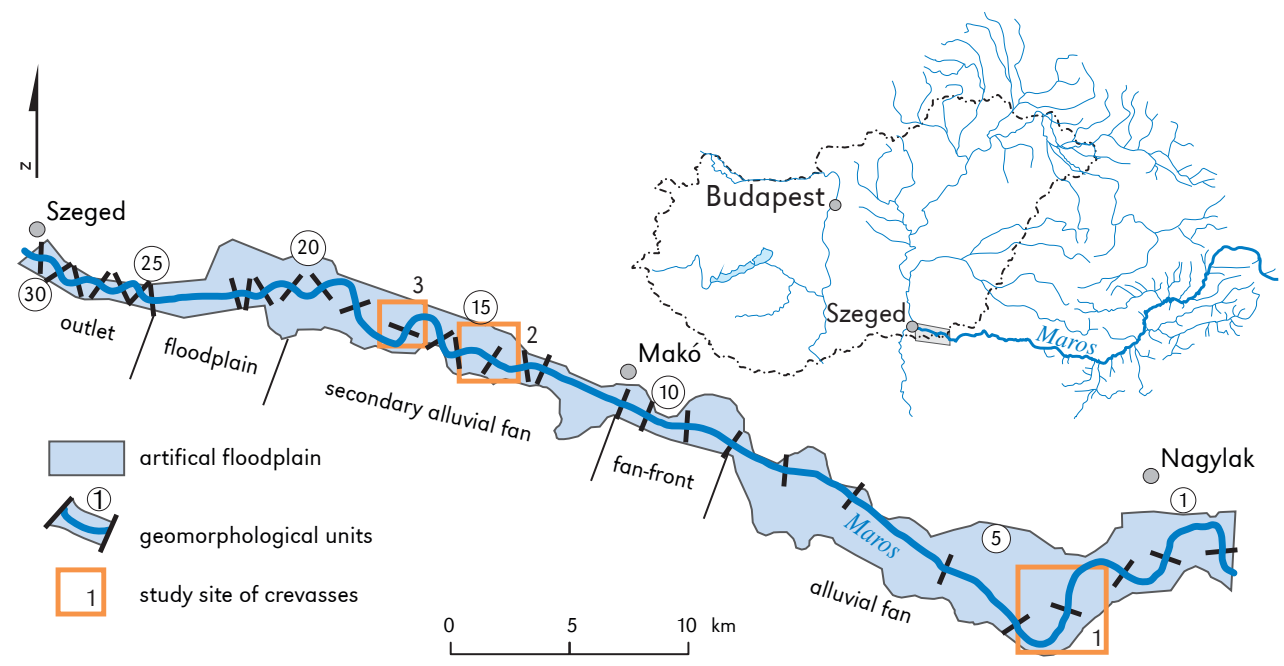

Figure 1. The research was carried out on the floodplain of the Maros River between Nagylak and Szeged. The area was dissected into geomorphological units (1-31). Crevasses were identified and analysed at 3 study sites

The discharge of the Maros at the Makó gauging station varies between $21-2450 \mathrm{~m}^{3} \mathrm{~s}^{-1}$ (Sipos, Kiss, \& Fiala, 2007). In the 19-20th centuries the floods lasted for 6-21 days $\mathrm{y}^{-1}$, however, in recent decades floods were missing or lasted just for 1-1.5 days (Kiss, 2014). The Tisza River also influences the duration of floods on the Maros, as the Tisza impounds the floods from the confluence up ca. 28 km (to Makó). The Maros has a considerable sediment discharge: the average amount of suspended load is $265 \mathrm{~kg} \mathrm{~s}^{-1}(8.3 \mathrm{mil}-$ lion $\left.\mathrm{t}^{-1}\right)$, and of the bed-load is $0.9 \mathrm{~kg} \mathrm{~s}^{-1}$ (28,000 t y ${ }^{-1}$; Bogárdi, 1971).

On the Maros river regulation works started in the 1850s (Ihrig, 1973). Continuous artificial levee system was built in the study area (Nagylak-Szeged), but along the upstream reach, the levee system is not continuous, as the villages were established on terraces. The levee system was built along the 19th c. meanders (the channel was straightened later; Ihrig 1973), thus the width of the floodplain varies $(0.5-3.5 \mathrm{~km})$. The river was shortened (from $260 \mathrm{~km}$ to $172 \mathrm{~km}$ ) by artificial cut-offs between Lipova and Szeged (18461871), thus the mean channel slope doubled (Laczay, 1975). The increased slope resulted in accelerated bank erosion and channel incision (ca. $1.0 \mathrm{~m}$ ), thus the amount of transported sediment greatly increased (Kiss, 2014), causing accelerated island and bar formation, which led to the development of islandbraided channel pattern in the upstream section (Sipos, 2006). The overbank aggradation was the most intensive $\left(1.2-2.5 \mathrm{~cm} \mathrm{y}^{-1}\right)$ at the time of channel and floodplain regulations as a consequence of increased sediment transport (especially after cut-offs), narrowed floodplain and more frequent floods (Kiss et al., 2011). In the 19-20th centuries the floodplain aggradation rate was outstanding compared to other rivers of the Carpathian Basin (Kiss et al., 2011), however, nowadays the role of floods is minor in the formation of floodplains, due to the decreased length of floods in connection with water retention and channel incision (Kiss et al., 2017). The lower section downstream of Makó was designed to have a sinuous pattern, and later, in the 20th c. this section was fixed by groynes and revetments. Since the 1950s the width of the channel decreases (Sipos, 2006) in connection with revetment constructions, water retention, water withdrawal (which caused flood duration decrease), and in-channel gravel 
mining (Kiss et al., 2017). The narrowing was the most intensive (12-15 $\left.\mathrm{m} \mathrm{y}^{-1}\right)$ in the 19501960s, then its rate decreased (Blanka, Sipos, $\&$ Kiss, 2006). The narrowing of the upper (island-braided and meandering) section was greater by $40 \%$ that of the lower sinuous section (Sipos, 2006). The process created new low-lying floodplain sections along the entire studied reach of the Maros (Kiss et al., 2017).

\section{Methods}

To study the width conditions of the channel and to identify narrowing sections, the banklines were digitised on the Third Military Survey (made in 1881, after the channel regulations) and on the LiDAR image (2014). The channel width was measured at every $100 \mathrm{~m}$ perpendicular to the centre-line model, the natural levees appeared as almost continuous forms along the slightly sinuous bends, whilst along meandering sections they were intercalated by point-bars. Therefore, the length of these forms could not be measured precisely, thus, it was not quantified. The width and height of natural levees and pointbars were defined in a similar way, drawing cross-sections perpendicular to the centreline of the river, across the highest point of the forms. In each unit, the measurements were made along with these profiles. The width of the forms was determined by the bankline on one side, while on the other by the breaking point of the slope (Fig. 2). Their relative height was measured from the bankline. The surface slope $\left(\mathrm{m} \mathrm{m}^{-1}\right)$ of the forms was calculated as the ratio of the relative height and width.

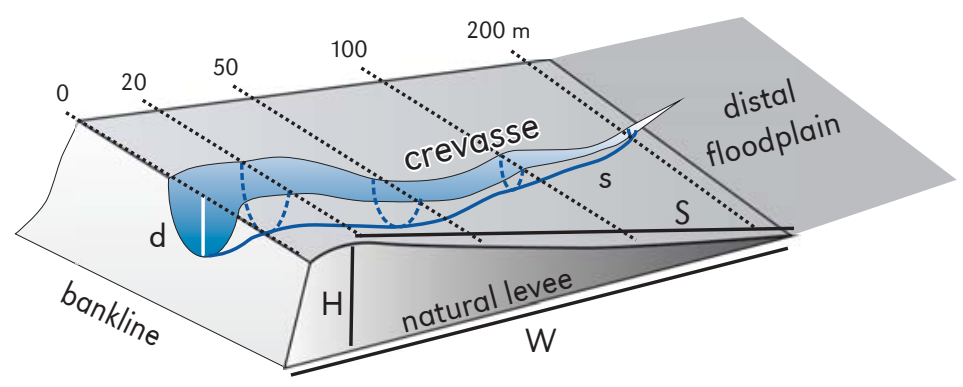

Figure 2. Morphometric parameters of natural levees (H: height, W: width, S: slope) and crevasses (d: depth, s: slope)

of the river. A digital elevation model based on LiDAR survey (vertical accuracy $\pm 0.1 \mathrm{~m}$ measured by RTK-dGPS; the DEM was provided by the Lower Tisza District Water Directorate) was applied to identify and measure the morphometric parameters of natural levees, crevasses, and point-bars. The studied floodplain area is bordered by constructed (artificial) levees and the state border between Romania and Hungary (Fig. 1). The measurements were done using ArcGIS 10.2 software.

The studied reach of the Maros was divided into 31 units (single meanders, bends or straight ones), which were separated by inflexion points. On the digital elevation
Crevasses appeared only at three units, where they were identified by using the Flow Direction tool in ArcGIS 10.2. Their depth was measured at 20, 50, 100, 250 and $500 \mathrm{~m}$ from the bankline (Fig. 2). The density of the crevasses $\left(\mathrm{km} \mathrm{km}^{2-1}\right)$ and their segmentation (junction $\mathrm{km}^{2-1}$ ) were also determined. The slope $\left(\mathrm{m} \mathrm{m}^{-1}\right)$ of the crevasses was calculated from their length and the height difference between their two ends.

\section{Results}

The channel of the Maros became considerably narrower in the last 130 years, as in 1881 the average width was 155 m (max: 
$490 \mathrm{~m}$; min: $60 \mathrm{~m}$ ) while in 2014 it reduced to $115 \mathrm{~m}$ (max: $176 \mathrm{~m}$; min: $72 \mathrm{~m}$ ). Thus, the average rate of narrowing was $0.3 \mathrm{~m} \mathrm{y}^{-1}$, and it affected $88 \%$ of the studied reach. The greatest width reduction was found for unit 13, where the maximum channel width was reduced by 77\% (1881: 490 m; 2014: $113 \mathrm{~m})$. The most intensive narrowing characterised the meandering and braided section (units 1-21), while the channel width of the slightly sinuous downstream section (units 22-31) remained the same, or at the apex of some bends, it even increased. The process of intensive channel narrowing enabled the development of point-bars and created new floodplain surfaces suitable for natural levee accumulation, though at a lower elevation.

\section{Natural levees}

In the study area, 32 active and 20 inactive natural levees were identified. In 16 units only active natural levees were identified, however in 15 units both active and inactive natural levees appeared, thus in some places double or triple natural levee systems developed as the bankline was removed from the forms due to channel narrowing.

The widest (1022 m) natural levee is located along a meander on the upstream section (unit 1), where the floodplain is wide (3400 m) and the rate of lateral channel shift is low $\left(0.3 \mathrm{~m} \mathrm{y}^{-1}\right)$. The height of this particular natural levee $(1.7 \mathrm{~m})$ is just about average $(1.7 \mathrm{~m})$, thus its slope is very low (0.0005). The highest $(3.1 \mathrm{~m})$ natural levee developed along a straight section (unit 15) and it is relatively narrow $(71 \mathrm{~m})$, therefore it has a greater slope (0.0436). In general, the narrowest natural levees have the greatest slopes (slope mean : 0.0428), while the wider forms have gen-

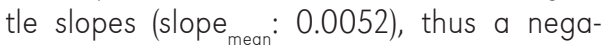
tive correlation was found between these parameters.

The narrowest active natural levee (width: $18 \mathrm{~m}$; height: $1.8 \mathrm{~m}$ ) developed on the new floodplain surface created by channel narrowing (unit 9). Here, a double natural levee developed, as along the inactive bankline the formation of the older natural levee terminated, and by the actual bankline a new, active form is evolving.

The size of the natural levees is influenced by the sinuosity of the channel. Usually, the natural levees along sharp meanders (sinuosity over 1.4) are 1.7-2.5 times wider, but no clear correlation exists between the height of the forms and channel sinuosity. However, the steepest natural levees are located along slightly sinuous sections.

As the locations of 19th c. artificial cutoffs and 20th c. channel narrowing are known, it is possible to evaluate their role in natural levee development. No cut-offs were made on the upstream section (units 1-6), thus here the natural levees are along three large meanders and they develop continuously (at least) from the 19th c. These old, and still active natural levees are wide

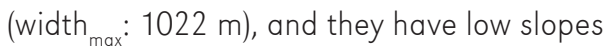
(slope max $_{\text {ma }}$ 0.0076). On the downstream part of the study area (units 7-31), several meander cut-offs were made, so those natural levees which belonged to them became inactive, and new forms started to develop along the new artificial channel. Thus, these young natural levees have been evolving just for ca. 150 years, therefore they are narrower (width max $: 768 \mathrm{~m}$ ), though they mean height is almost at the average of all levees (height $1.7 \mathrm{~m}$ ), as a consequence, they

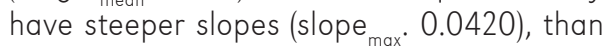
of the natural levees along the upstream section. The youngest natural levees evolved on the new, low-lying floodplain sections created by channel narrowing, resulting in the inactivity of the previous natural levees (Fig. 3). Altogether, they appear in 12 channel units. These young levees are narrow (width max $: 79 \mathrm{~m}$ ), but they are the highest (height ${ }_{\text {max }}: 3.1 \mathrm{~m}$ ) forms, thus they have the steepest slopes (slope max $_{0}$ 0.0991). As narrowing is a quite new process, behind these new natural levees additional older and nowadays inactive natural levees could be identified. 


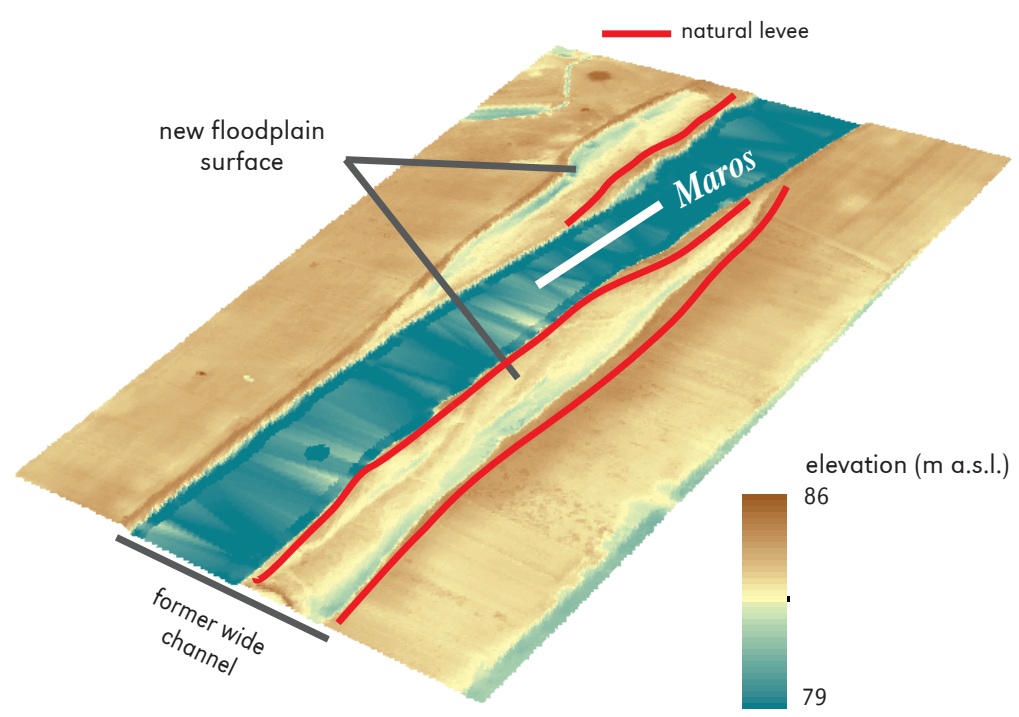

Figure 3. Natural levees could develop behind each other. In the given case younger natural levees developed on low-lying floodplain surfaces created by channel narrowing

\section{Crevasses}

Crevasse systems developed just along such sections where no meander cut-off was made and the channel remained almost in the same position due to low $\left(\leq 0.3 \mathrm{~m} \mathrm{y}^{-1}\right)$ lateral erosion (units 3-4, unit 15, and units 18-19; Fig. 4). The lateral shift of the channel along these sections is inhibited by cohesive bank material (No. 1. study site) or revetments (No. 2-3 study sites). Identifiable crevasses did not appear along other sections.

The uppermost crevasse system developed along with a meander (No. 1 study site; Fig. 4), where the slope of the Maros is great (0.00038). The mean depth of these crevasses is $0.7 \mathrm{~m}$ (depth max $_{0}: 0.8 \mathrm{~m}$ ) at $20 \mathrm{~m}$ far from the bankline, and towards the distal parts (50-500 $\mathrm{m}$ from the bankline) it decreases to $0.4 \mathrm{~m}$ in average. The deepest crevasse (depth $_{\max }: 0.8 \mathrm{~m}$ ) developed at the apex of the meander. In this study area, the crevasses are generally short (400-600 m) and they terminate at the rim of the natural levees, because here the cultivation (ploughing) already levelled all fluvial forms. In the study area, the total length of the crevasses is $6.6 \mathrm{~km}$, thus their mean density is $2.2 \mathrm{~km} \mathrm{~km}^{2-1}$, and they are not segmented (1.0 junction $\mathrm{km}^{2-1}$ ), probably because they stretch just to the edge of the natural levees. The mean slope of the crevasses is 0.00015 . The longest (length max : $1.6 \mathrm{~km}$ ) and the steepest (slope max $_{0}: 0.00030$ ) crevasse developed behind a point-bar in the southern part of the study area (indicated by red column on Fig 4, Study site 1), thus during floods it could act as a chute channel.

On the lower section of the Maros crevasses developed along a slightly bending section (No. 2 study site) with 0.00012 mean water slope; and along a meander (No. 3 study site) with 0.00005 slope. In No. 2. study site the crevasses are easily identifiable (Fig. 4), as their mean depth is $1.5 \mathrm{~m}$ (varies between 1.0-1.8 $\mathrm{m}$ ) at $20 \mathrm{~m}$ far from the bankline. Farther from the bankline, at $50 \mathrm{~m}$ distance, their depth reduces to 0.7-0.9 $\mathrm{m}$, and their distal sections become even shallower (at $250 \mathrm{~m}$ : $0.6 \mathrm{~m}$; at $500 \mathrm{~m}$ : $0.4 \mathrm{~m}$ ). The density of the crevasse system is $2.7 \mathrm{~km} \mathrm{~km}^{2-1}$, they have more junctions (4.0 junctions $\mathrm{km}^{2-1}$ ), and their mean slope is 0.00017 , thus all parameters are greater than in the No. 1. study site. Here the steepest crevasse (slope max $_{0}: 0.00041$ ) also developed at the apex of the bend. 
No. 3 study area

(No. 18-19 units)

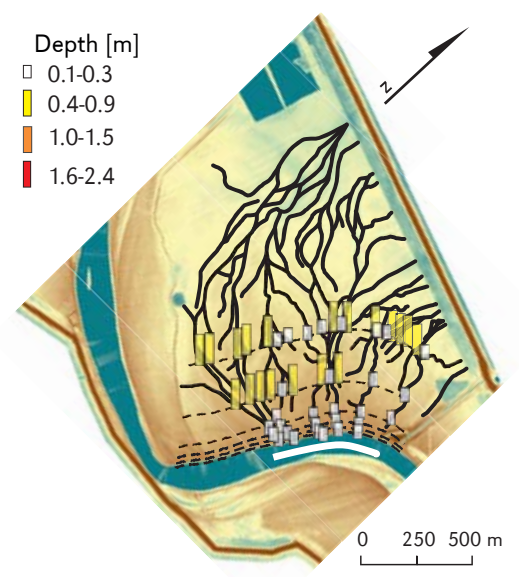

No. 2 study area

(No. 15 unit)

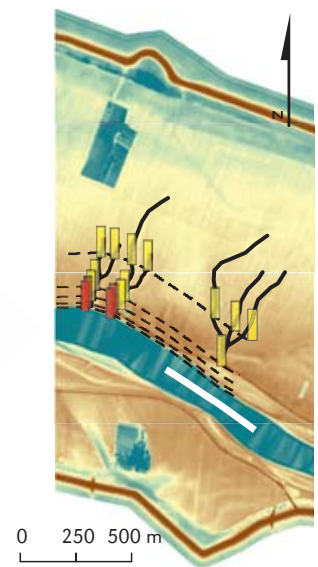

No. 1 study area

(No. 3-4 units)

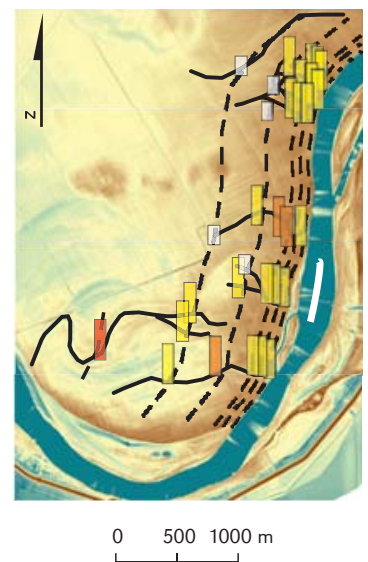

Figure 4. Crevasse systems were identified at three sites. The depth conditions of the crevasses were measured at given distances (0-20-50-100-200-500 m) from the bankline

The No.3 study site is also located on the downstream section of the Maros, but in contrast to the previous site, it is located at a meander (Fig. 4). Here the crevasse system is the most complex, as its density $\left(8.4 \mathrm{~km} \mathrm{~km}^{2-1}\right)$ is 3-4 times higher than of the upstream areas. The crevasses terminate in artificial clay pits in front of the constructed levees. The crevasses are quite shallow (0.1-0.3 m) near the bank (at $20 \mathrm{~m}$ ), but they are getting deeper towards the distal part of the floodplain (50-500 m zones), as their mean depth increases to $0.4 \mathrm{~m}$ (depth max $_{\text {: }}$ $1.0 \mathrm{~m}$ ). The crevasses create a complex system, as it is reflected by their high segmentation (21 junctions $\left.\mathrm{km}^{2-1}\right)$. However, the mean slope of the crevasses $(0.00015)$ is similar to the other study areas, but considerably higher than the mean water slope of the main channel. The steepest crevasse (slope max $_{\text {: }}$ 0.00032 ) is located at the apex of the meander, where the thalweg is probably situated closest to the bank.

\section{Point-bar systems}

Point-bars were identified at 26 bends, but only 18 point-bars are actively forming, while at 9 meanders the point-bar systems became inactive as the result of 19 th $\mathrm{c}$. artificial cutoffs.

The inactive point-bar systems are different on the upper and lower units. In the upper units (units 9-11) the point-bar systems are wide (524-1133 m) containing 11-34 ridges. The width of the individual point-bars is 63-79 m. In contrary, in the lower units (units 17-24) the point-bar systems have only 5-22 ridges, and they are narrower (172$921 \mathrm{~m})$, but the width (50-115 m) of individual point-bars is higher (Fig. 5). Though the maximum height of the point-bars $(0.3-1.0 \mathrm{~m})$ does not reflect a downstream trend, but within the point-bar systems the ridges have characteristic height changes. In the upper units the highest point-bars are located in the youngest third of the point-bar system, whilst in the downstream units, the highest ridges are always located right on the banks of the cut-off meanders.

The active point-bar systems are less developed, as in the upper units (units 1-4) they have only 6-11 members and their width changes between 265 and $926 \mathrm{~m}$. Their height is 0.9-1.4 m (height $t_{\text {mean }}: 1.2 \mathrm{~m}$ ), and it decreases downstream. In contrast, 


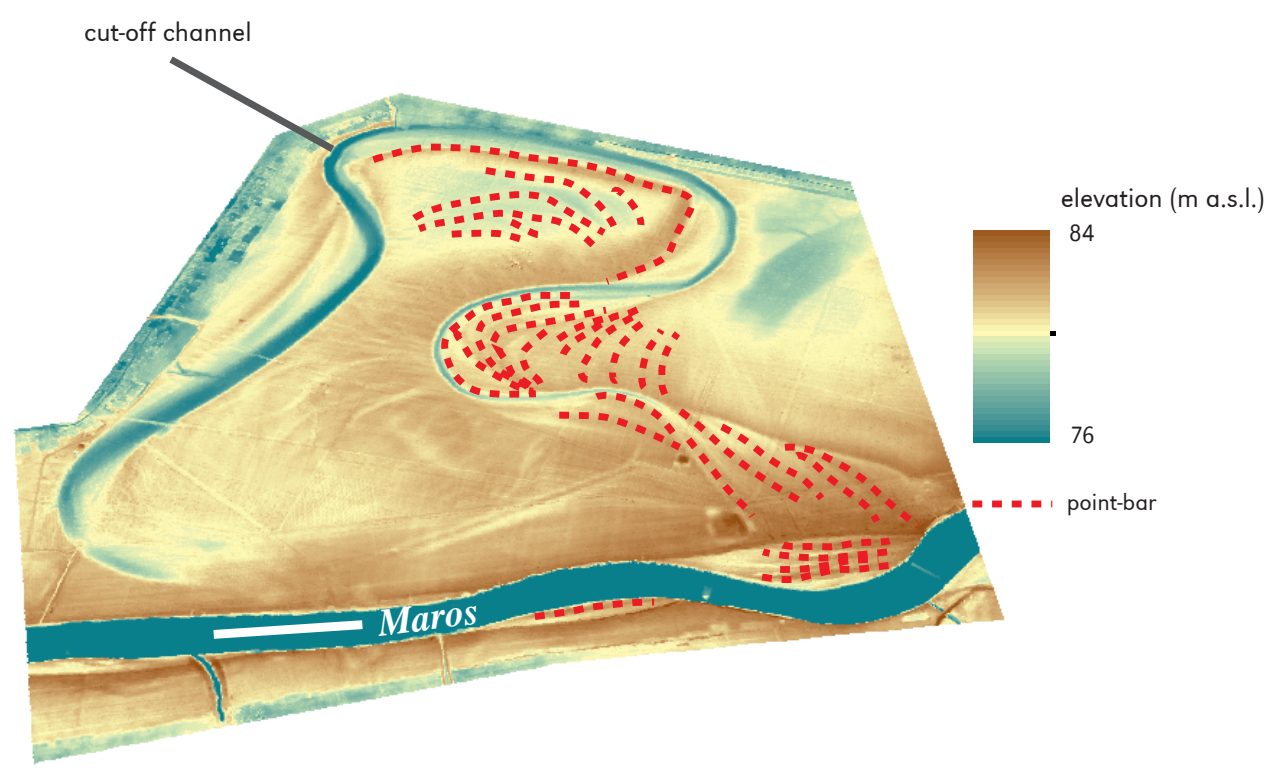

Figure 5. Point-bar systems became inactive along an artificially cut-off channel, but new, active ones developed along the new channel

in the downstream units (units 13-31) the number of point-bars is more variable (4-13), but the width of the point-bar system is only 96-709 $\mathrm{m}$, and they are slightly lower (0.4-1.5 m; mean. 0.8 m).

\section{Discussion}

\section{General morphology of natural levees and point-bars}

On the floodplain of the $53.7-\mathrm{km}$ long reach of the Maros River the LiDAR-based DEM enabled us to identify $0.3-3.1 \mathrm{~m}$ high natural levees, 0.3-2.0 m deep crevasses breaking through the natural levees and 0.4$1.5 \mathrm{~m}$ high point-bars which form point-bar systems. Whilst natural levees and point-bars were identifiable along the whole reach of the Maros, crevasses appeared just in three areas.

The natural general trend in the dimensions of the forms is surpassed by direct and indirect human impacts: the channel development is modified by cut-offs and narrowing, the floodplain evolution is restricted by constructed levees which are located to various distances from the channel, and finally the surface of the floodplain is modified by planation (ploughing) and excavation (clay-pits). The horizontal growth of natural levees could be limited by constructed levees, clay-pits and other artificial forms (e.g. small dikes, elevated roads, canals).

Along the upper part of the studied reach of the Maros (units 1-12) the lateral growth of the natural levees is not limited by constructed levees, as here the floodplain is wide $(3.4 \mathrm{~km})$. Besides, here the meanders develop for centuries (at least they have existed in their present form since the first surveys of the 18th c.), thus hundreds of floods could accumulate the material of the natural levees, widening them and creating gentle slopes, but at the same time the low rate of lateral channel shift $\left(0.3 \mathrm{~m} \mathrm{y}^{-1}\right)$ did not destroy them. These factors created favourable conditions for a long and undisturbed evolution for both the natural levees and their crevasse systems. On the opposite bank, active point-bars and point-bar systems developed. These are the highest and widest point-bars of the study area, as the slow lateral channel migration 
did not allow point-bar development over extensive areas, thus their rather increased in height and width; and instead of the development of point-bar system with a high number of members, only some point-bars build them up.

In contrast, along the downstream section (units 13-31) the evolution of the natural levees is controlled by the quite narrow $(1.6 \mathrm{~km})$ floodplain, the fast lateral migration of the channel (1.2 $\left.\mathrm{my}^{-1}\right)$, and river engineering works. Here the bends are very close to the constructed levees, therefore, the lateral expansion of the natural levees is limited and their vertical growth could result in the general aggradation of the floodplain. Here the 19-20th c. clay-pits in front of the constructed levees also influence the development of the natural levees, as primarily the material is deposited here, and the natural levee as a positive form could appear on the digital elevation map only after the clay-pit is filled up. Along this section the development of the point-bars matches to the fast channel migration too, thus they have more numerous, narrower and slightly lower ridges.

\section{General morphology of crevasses}

Crevasse systems are limited to only three sections, where the channel is at the same location for centuries and the old natural levees are active. The depth of the crevasses varies with the three study areas: in the upper two sites the crevasses are incised to the half of the height of the natural levees, whilst on the most downstream site they are incised just to $20-25 \%$ of the natural levees. The densest and shallowest crevasse system developed on the lowermost section with the lowest slope of the Maros. It could be explained by the length of floods, as at the given section the impoundment of floods is typical: when the floods of the Tisza and Maros coexist, the flood of the Maros is blocked by the backwater effect. Therefore, in the lower section floods are longer and slower, thus, more time is available for the development of a dense crevasse system, however, the stream power is not enough for their deep incision.

The slope of the crevasses is higher by an order than the slope of the Maros; but while the slope of the river decreases downstream, the slopes of the crevasses remain similar. The deepest and steepest crevasses developed at the apex of bends and meanders, where the thalweg is closest to the bankline, thus the flow in the crevasse could be the most powerful. In the lowermost study area, at their entrance crevasses are very shallow. Just in comparison: $20 \mathrm{~m}$ far from the bankline in uppermost No. 1 study area the mean crevasse depth is $0.6 \mathrm{~m}$, in No. 2 study area it is $1.5 \mathrm{~m}$, and at the lowermost No.3 study area the crevasses are only $0.2 \mathrm{~m}$ deep on average. At the same time, the depths at the distal parts of the crevasses are the same: at $250 \mathrm{~m}$ they are uniformly 0.4-0.5 m deep. Thus, at the lowermost study area probably a sediment plug developed in the crevasses during an impounded flood.

The development and preservation of the forms are highly influenced by direct and indirect human impact. The crevasses could drain water into the deep clay-pits in front of the natural levees, thus artificial hollows could support their water-draining function, and serve as sediment sinks. Therefore, the artificial excavational forms could sustain their development and long existence. In contrast, the ploughing of agricultural fields could destroy the shallow crevasses, especially in the distal part of the floodplain. On the other hand, water retention related flood frequency decrease contributes to their aggradation, as sediment plugs developed at their proximal parts.

\section{Human impact on natural levee and point-bar development}

Human impact is a very important controlling factor on the evolution of natural levees and point-bar systems, as in both cases active and inactive forms were identified. Active natural levees and point-bars develop along the actual bank-line, whereas their terminated 
development is clearly related to bank-line changes, which is explained by artificial cutoffs and channel narrowing caused by indirect human impacts. In this way, not only series of point-bars developed, but also double or even triple natural levees, which is quite unlikely on natural, equilibrium floodplains.

Altogether, six natural levee and point-bar generation types are distinguishable along the Maros River (Fig. 6):

A) well-developed natural levee and point-bar system at the time of the 19 th c. river regulations with

A1) continuous development ever since;

A2) terminated development due to channel narrowing since the 1950s;

A3) terminated development due to an artificial cut-off in the 19th c.;

B) natural levee and point-bar system development started during the 19 th c. river regulations, when a cut-off was made and a new channel was created, and the form has

B1) continuous development since that time;

B2) terminated development due to channel narrowing since the 1950s;

C) the youngest, actively forming natural levee and point-bar started to develop when the channel became narrower (since the 1950s) and on the new floodplain section the evolution of the natural levee could start.
Natural levees belonging to the A1 type develop for centuries, thus, they are the widest (width mean $_{4}: 41 \mathrm{~m}$, width max $1022 \mathrm{~m}$ ) forms in the study area, their mean height (heightmean $: 1.8 \mathrm{~m}$ ) is the greatest of all types (Fig. 7, Tab. 1), thus these natural levees have the smallest slope too (slope mean $_{\text {: }}$ 0.0016-0.0076). The crevasses developed just across this type of natural levee. As the evolution of A2-type natural levees was long, but it terminated by channel narrowing in the mid-20th c., they are narrower (width mean $_{173} \mathrm{~m}$, width max $_{\text {: }}$

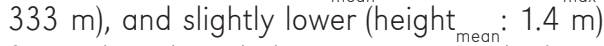
forms than those belong to A1 type. The largest number of old natural levees belongs to the A3 type. Their width is similar to A2, but their average height (height mean $_{1}: 1.1 \mathrm{~m}$ ) is the lowest in class A, as due to the cut-offs they got far from the active channel during the last ca. 150 years. The spatial distribution of these types is determined by the spatiality of the 19th c. regulation works. The A1 and A2 type levees survived where the meanders of the Maros were not very sharp, thus they were not cut off. Such, unmanaged units are located in the upstream (1-3 units) and in the middle section (10-19 units). As the evolution of the $\mathrm{A} 3$ type terminated by cut-offs, they are mostly located where the channel was straightened, thus they are found behind the members of class $B$.

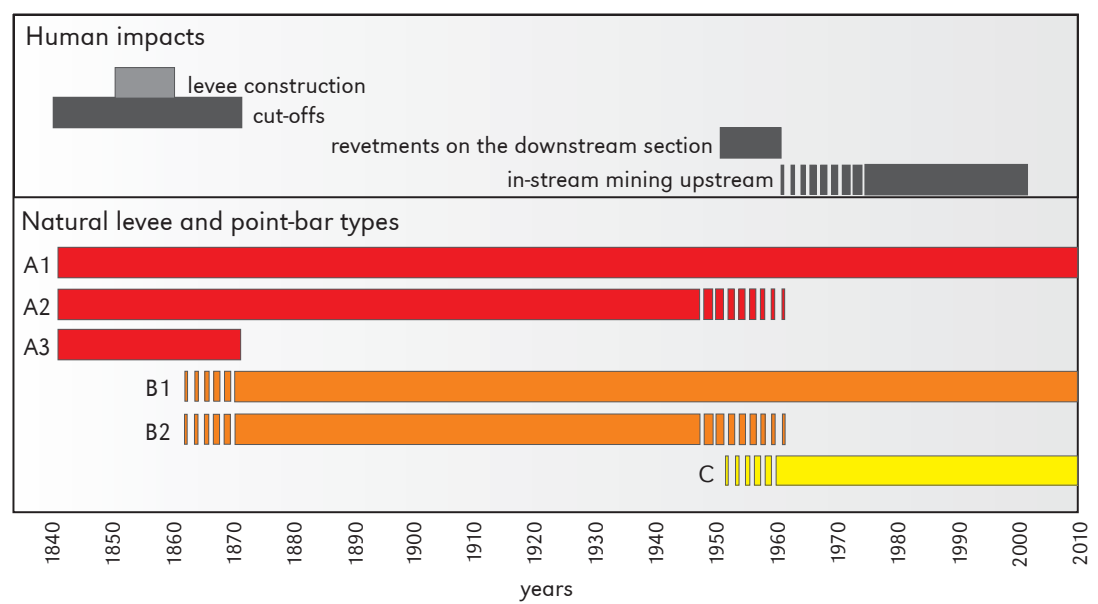

Figure 6. Development types of natural levees and point-bars related to various human impacts 

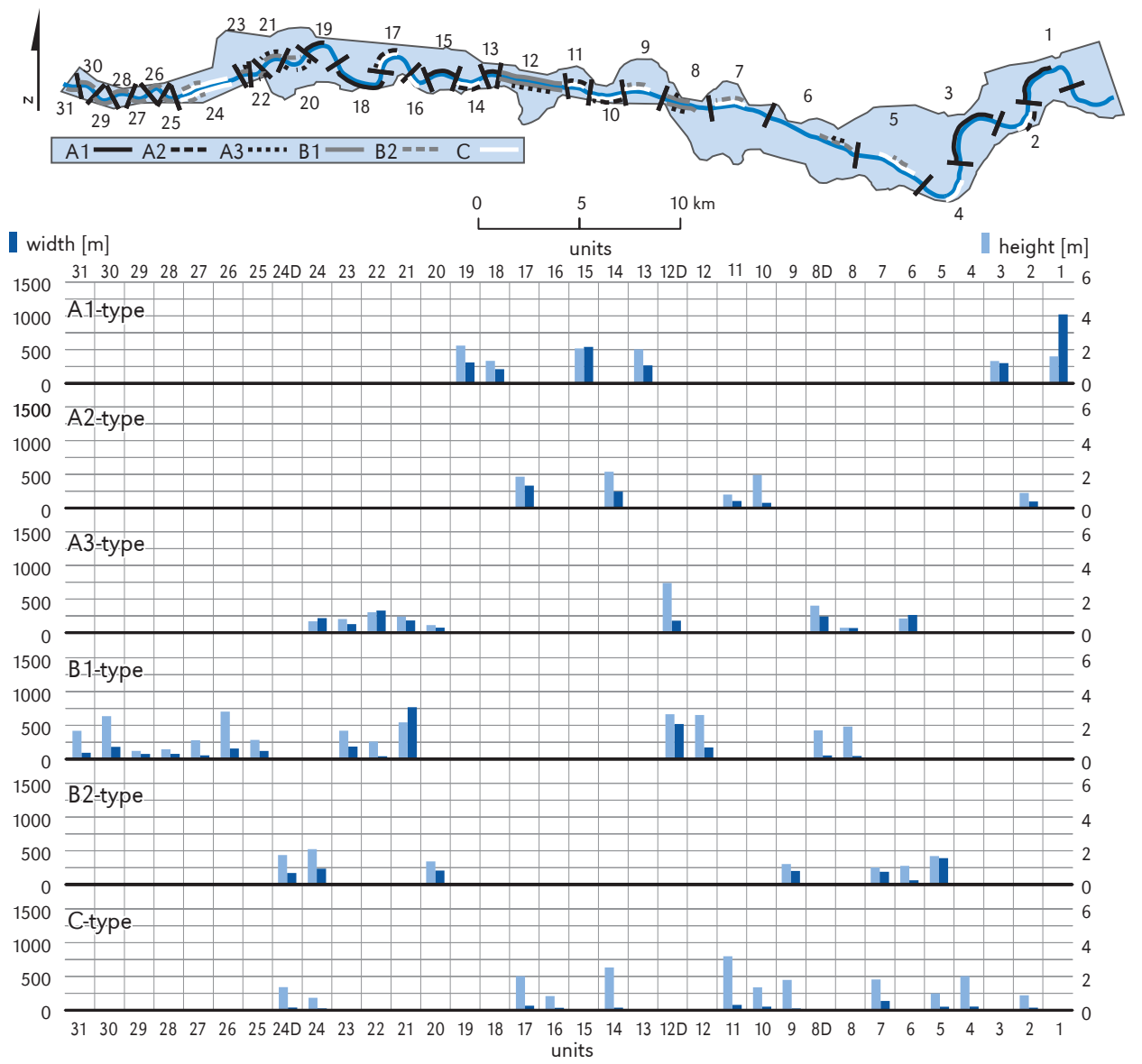

Figure 7. Type and morphometric parameters (width and height) of the identified natural levees at a given unit

Table 1. Main characteristics of the identified natural levee types (n: number of studied forms)

\begin{tabular}{|c|c|c|c|c|c|c|c|c|c|c|}
\hline \multirow{2}{*}{ Type } & \multirow{3}{*}{$\mathrm{n}$} & \multicolumn{3}{|c|}{ Width $[\mathrm{m}]$} & \multicolumn{3}{c|}{ Height $[\mathrm{m}]$} & \multicolumn{3}{c|}{ Slope $\left[\mathrm{m} \mathrm{m}^{-1}\right]$} \\
\cline { 3 - 11 } & & min & mean & $\max$ & min & mean & max & min & mean & max \\
\hline A1 & 6 & 210 & 441 & 1022 & 1.3 & 1.8 & 2.2 & 0.0016 & 0.0052 & 0.0076 \\
A2 & 4 & 78 & 173 & 333 & 0.8 & 1.4 & 1.9 & 0.0056 & 0.0074 & 0.0092 \\
A3 & 9 & 69 & 187 & 329 & 0.3 & 1.1 & 2.9 & 0.0031 & 0.0061 & 0.0165 \\
B1 & 14 & 42 & 182 & 768 & 0.4 & 1.7 & 2.8 & 0.0051 & 0.0159 & 0.0420 \\
B2 & 7 & 63 & 208 & 391 & 1.0 & 1.5 & 2.1 & 0.0043 & 0.0084 & 0.0174 \\
C & 12 & 18 & 46 & 79 & 0.7 & 1.6 & 3.1 & 0.0220 & 0.0428 & 0.0991 \\
\hline
\end{tabular}

B-type natural levees have been developing since the 19th c. cut-offs, on the newly created, usually straight or slightly sinuous channel sections. Their width (width ${ }_{\text {mean }}$ : 182$208 \mathrm{~m}$ ) and height (height ${ }_{\text {mean }}: 1.5-1.7 \mathrm{~m}$ ) are almost the same, or higher, than of the $\mathrm{A} 2$ and 
A3 types (Tab. 1), whilst their slope (slope mean $_{\text {: }}$ 0.0084-0.0159) is greater. Probably, this could be explained by the disturbance itself, as at the time of the regulations the amount of sediment transport increased exceptionally (Kiss, 2014), as only a narrow pilot-channel was dug, and the river had to erode the new channel for itself, producing extra sediment load. Thus, an increased amount of sediment was available for the rapid evolution of new natural levees. As the development of B2 type levees stopped due to channel narrowing, their parameters are slightly lower than of the continuously developing B1. The channel of the Maros was straightened in the upper section (units 5-12), and downstream of the 20th unit, the B1 and B2 type natural levees appear along with these units.

The members of class $C$ are the youngest, as they evolved on the new, low-lying floodplain surfaces formed by channel narrowing (Kiss et al., 2017, 2018). Though these forms are the narrowest (width mean $: 46 \mathrm{~m}$ ),

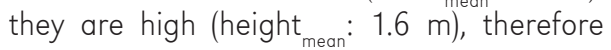
they have the steepest slopes (slope mean $_{\text {: }}$ : $0.0428 ;$ Tab. 1). As they all developed on the low-lying surfaces, their aggradation is very intensive, primarily because small but more frequent flood-waves could accumulate sediment here, secondary because these (nearbankfull) floods transport the highest amount of sediment. In contrary, on the higher floodplain sections, the older natural levees could evolve just during exceptionally large floods (Kiss et al., 2018). C-type natural levees are almost evenly distributed along the studied reach of the Maros, as almost the whole reach is intensively narrowing, though near to the confluence (units 25-31) the members of the C-type are missing, as here the channel slightly widened.

The point-bar systems could be grouped to the same classes as the natural levees, as they developed on the other side of the channel under similar direct or indirect human impacts. A-type point-bar systems have the longest development. A single A1 type pointbar system survived (unit 15) containing only 7 ridges, which follow the slight incision of the channel, thus their height decreases towards the channel (Fig. 8, Tab. 2). The A2 type pointbar systems developed for a long time, but their evolution was stopped by the narrowing of the channel, and they have no active point-bar surface. Their mean height is similar to the A1, but the highest point-bar is usually located at the channel, thus only high floods could built them, thus their morphology changes towards of a natural levee. The development of the A3 type point-bar systems was terminated by the 19th century artificial cut-offs. They contain the largest number of point-bars (4-17) referring to rapid meander migration before the channel regulations (therefore these meanders had to be straightened). Their mean height is similar to $A 1$, but - similarly to $A 2$ - the highest ones are located by the cut-off channel. It could be explained by way of channel regulations: the cut off was made applying narrow pilot channels, thus in the cut-off section water flow decreased gradually during one or two decades. As the sediment load and the flood levels of the Maros increased during the regulation works, they resulted in very intensive point-bar formation during the slow decline of the cut-off channels.

The B-type point-bars develop since the 19th c. channel regulation along the artificially created sinuous channel sections. They are higher than of the members of the A-class, but height conditions of the point-bar members show no clear tendency towards the channel. Usually, they are getting narrower towards the active channel, referring to less active formation since the channel regulations.

The C-type of point-bar systems is the youngest, as they develop on the new, lowlying floodplain surfaces created by channel narrowing. Though they are young, they already contain 3-7 ridges, but these are the highest and narrowest ones of all point-bar systems, similarly to the C-type of natural levees. The development of the C-type pointbars the most closely related to channel dynamics: at intensively narrowing channel sections they develop very rapidly, thus their 

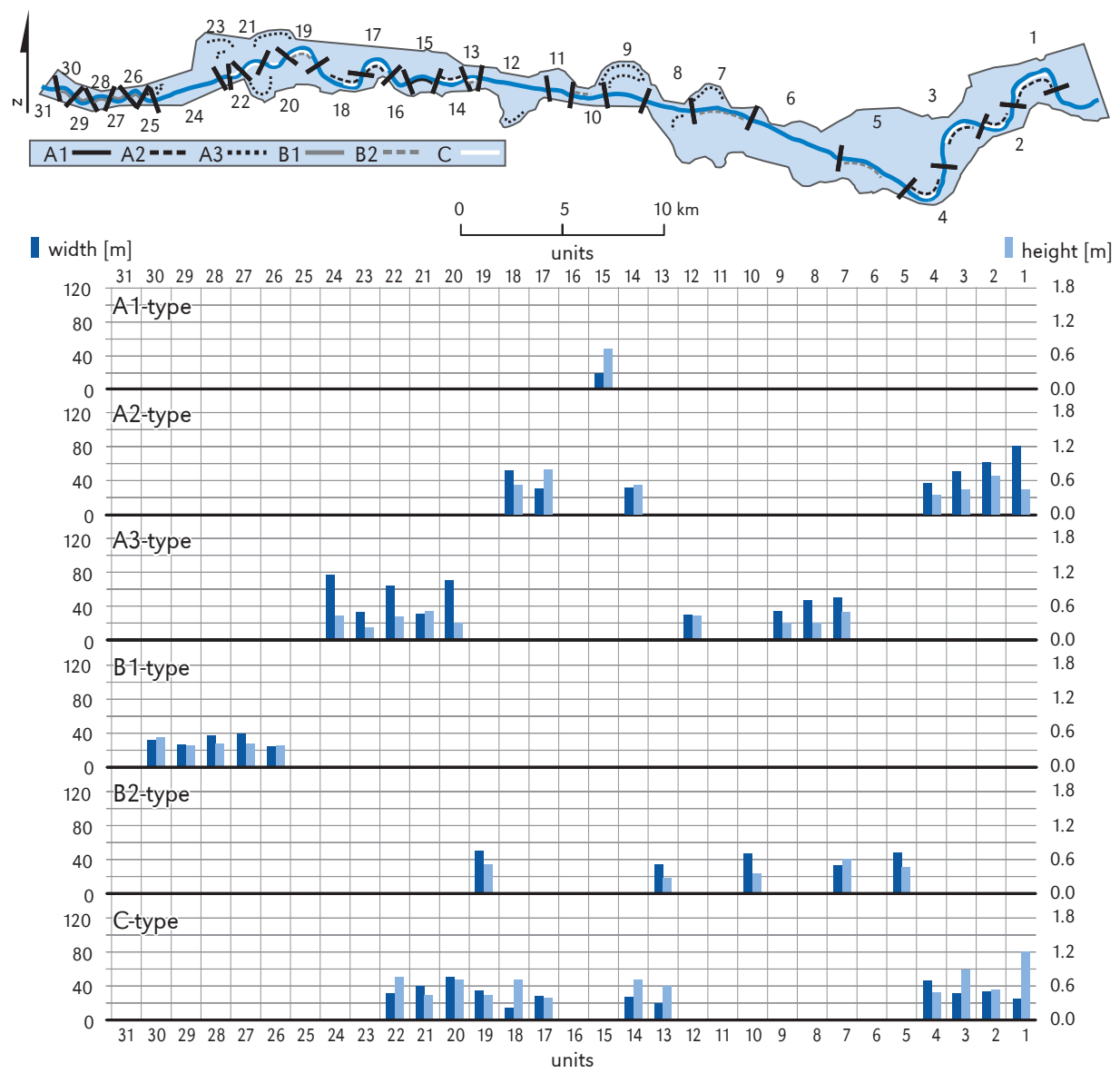

Figure 8. Type and mean morphometric parameters (width and height) of the identified point-bars at a given unit

Table 2. Main characteristics of the identified point-bar systems

\begin{tabular}{|c|c|c|c|c|c|c|c|c|}
\hline \multirow{2}{*}{ Type } & \multicolumn{2}{|c|}{ Point-bar systems } & \multicolumn{6}{|c|}{ Single point-bar within point-bar systems } \\
\cline { 3 - 9 } & \multicolumn{2}{|c|}{} & \multicolumn{3}{|c|}{ height } & \multicolumn{4}{c|}{ width } \\
\cline { 2 - 9 } & members & $\begin{array}{c}\text { mean width } \\
{[\mathrm{m}]}\end{array}$ & $\begin{array}{c}\text { min. } \\
{[\mathrm{m}]}\end{array}$ & $\begin{array}{c}\text { mean } \\
{[\mathrm{m}]}\end{array}$ & $\begin{array}{c}\text { max. } \\
{[\mathrm{m}]}\end{array}$ & $\begin{array}{c}\text { min. } \\
{[\mathrm{m}]}\end{array}$ & $\begin{array}{c}\text { mean } \\
{[\mathrm{m}]}\end{array}$ & $\begin{array}{c}\text { max. } \\
{[\mathrm{m}]}\end{array}$ \\
\hline A1 & 7 & 165 & 0.2 & 0.4 & 0.9 & 12 & 24 & 58 \\
A2 & $6-10$ & 477 & 0.2 & 0.5 & 1.4 & 8 & 58 & 139 \\
A3 & $5-34$ & 579 & 0.1 & 0.4 & 1.0 & 6 & 49 & 115 \\
B1 & $5-7$ & 159 & 0.2 & 0.5 & 1.5 & 6 & 29 & 63 \\
B2 & $4-13$ & 268 & 0.2 & 0.5 & 1.6 & 8 & 141 & 132 \\
C & $3-7$ & 121 & 0.3 & 0.6 & 1.7 & 8 & 30 & 60 \\
\hline
\end{tabular}


height is decreasing towards the channel, while along less intensively narrowing sections their height is increasing, due to the limited lateral aggradation.

\section{Conclusions}

The detailed LiDAR-based DEM enabled us to identify the fluvial forms of the floodplain and to analyse their morphology. Earlier studies had already emphasized the role of human impact on various rivers (Gregory, 2004; Steiger et al., 2005), however they usually focused on their hydrological or channel pattern changes (Łajczak, Plit, Soja, Starkel, \& Warowna, 2006, Sipos et al., 2007), but in lack of detailed elevation data on floodplain forms it was impossible to evaluate the human impact on floodplain form assemblage. However, Falkowski (1990) theoretically proved, that various development state of the river channel (e.g. young or mature) resulted in different floodplain forms and sedimentary environments, thus we could also suppose that creating artificial channel sections and cutting off meanders could influence floodplain forms.

The 18 artificial cut-offs shortened the studied length of the Maros by $38 \%$, while channel narrowing affected $88 \%$ of the reach. The narrowing is connected to (1) the incision of the base level (Tisza River) caused by channel regulation (Kiss, 2014), (2) in-stream gravel mining (Urdea, Sipos, Kiss, \& Onaca, 2012), (3) dam and reservoir constructions, and (4) the resulted decreasing frequency and magnitude of floods (Kiss, 2014). Both human impacts resulted in the disconnection of the older natural levees, crevasses, and point-bars from the channel, thus their classical development terminated, though during large floods suspended sediment could be deposited on their surface. On the contrary, along the artificially created channel sections, and on the newly developed low-lying floodplain surfaces new natural levees and point-bar systems develop. Their rapid evolution is reflected by their considerable height, as during the disturbance (digging new pilot channels) the sediment transport of the Maros increased considerably (Kiss et al., 2014), supporting the rapid evolution of the studied near bank forms. However, crevasses were not identified in these areas, thus the form assemblage impoverished due to human impact.

Based on the spatial and temporal characteristics of the natural levees and pointbar systems six generation types were distinguished, considering the beginning (i.e. pre-19th c., 19th c., and 20th c.) and the end of their development (19th c., 20th c., or still active). These differences are undoubtedly connected to human impact on the river.

The studied natural levees, crevasses and point-bar systems could be considered as coupling forms between the channel and the floodplain, as the development of these floodplain forms is primarily controlled by water and sediment transport. From this point of view, the studied forms on the Maros floodplain reflect weakening connection between the channel and the floodplain, as their development is not continuous and undisturbed, nor in space neither in time. Even the development of the newly born (19-20th c.) natural levees and point-bars could terminate, if the channel narrowing continues in the future, thus gradually the floodplain will be decoupled.

Comparing the size of the floodplain forms of the Maros with other river's (see Bown \& Kraus, 1987; Brierley et al., 1997; Cazanacli \& Smith, 1998), it seems that the dimensions of the natural levees are quite different, depending on the water and sediment discharge of the rivers, the width of the floodplain and the human impacts.

\section{Acknowledgement}

The research was supported by the Hungarian Research Foundation (OTKA 119193). Thanks for Prof. G. Mezősi for his useful advices and support.

Editors' note:

Unless otherwise stated, the sources of tables and figures are the authors', on the basis of their own research. 


\section{References}

Allen, J.R.L. (1965). A review of the origin and characteristics of recent alluvial sediments. Sedimentology, 5, 89-191. https://doi.org/10.1111/j.1365-3091.1965.tb01561.x

Asselman, N.E.M., Middelkoop, H. (1998). Temporal variability of contemporary floodplain sedimentation in the Rhine-Meuse Delta, the Netherlands. Earth Surface Processes and Landforms, 23, 595-609. https://doi.org/10.1002/(sici)1096-9837(199807)23:7<595::aid-esp869>3.0.co;2-y

Blanka, V., Kiss, T. (2006). Case study on meander development of the downstream section of River Maros. Hidrológiai Közlöny 86(4), 19-22. [in Hungarian]

Blanka, V., Sipos, Gy., Kiss, T. (2006). Spatial and temporal changes of meander formation on the Hungarian section of the River Maros. In Kertész, Á., Dövényi, Z., Kocsis, K., (Eds.), III. Magyar Földrajzi Konferencia (pp. 1-10), Budapest: MTA-FKI. [in Hungarian]

Bogárdi, J. (1971). Sediment transport of rivers. Budapest, Hungary: Akadémiai Kiadó. [In Hungarian].

Bown, T.M., Kraus, M.J. (1987). Integration of channel and floodplain suites, I. Developmental sequence and lateral relations of alluvial paleosols. Journal of Sedimentary Petrology, 57, 587-601. https://doi.org/10.1306/212f8bb1-2b24-11d7-8648000102c1865d

Branß, T., Dittrich, A., Núñez-González, F. (2016). River flow. In Constantinescu G., Garcia M., Hanes D. (Eds.), Reproducing natural levee formation in an experimental flume (pp. 1122-1128.), London: Taylor \& Francis Group.

Bridge, J.S. (2003). Rivers and floodplain: Form, processes, and sedimentary record. Oxford: Blackwell,.

Brierley, G.J., Ferguson, R.J., Woolfe, K.J. (1997). What is a fluvial levee? Sedimentary Geology, 114(1-4), 1-9. https://doi.org/10.1016/S0037-0738(97)00114-0

Brierley, G.J., Hickin, E.J. (1992). Floodplain development based on selective preservation of sediments, Squamish River, British Columbia. Geomorphology 4, 381-391.

https://doi.org/10.1016/0169-555X(92)90033-K

Brown, A.G. (1983). An analysis of overbank deposits of a flood at Blandford-Forum, Dorset, England. Revue Geomorphologie Dynamique, 32(3), 95-99.

Cazanacli, D., Smith, N.D. (1998). A study of morphology and texture of natural levees, Cumberland Marshes, Saskatchewan, Canada. Geomorphology, 25, 43-55.

https://doi.org/10.1016/S0169-555X(98)00032-4

Chalov, R.S. (2004). Morphological expressions of river sediment transport and their role in channel processes. IAHS Publication, 288, 205-211.

Coleman, J.M. (1969). Brahmaputra River: Channel processes and sedimentation. Sedimentary Geology, 3, 129-239.

Dietrich, W.E., Wilson, C.J., Reneau, S.L. (1986). Hollows, colluvium, and landslides in soil-mantled landscapes. In Abrahams, A.D. (Ed.), Hillslope processes (pp. 361-388). Boston: Allen and Unwin.

Falkowski, E. (1990). Morphogenetic classification of river valleys developing in formerly glaciated areas for the needs of mathematical and physical modelling in hydrotechnical projects. Geographia Polonica, 77(2), 55-68.

Fisk, H.N. (1947). Fine-grained alluvial deposits and their effects on Mississippi River activity. Vicksburg, Miss.: Waterways Experiment Station, Mississippi River Commission.

Fryirs, K.A., Brierley, G.J. (2012). Geomorphic analysis of river systems: An approach to reading the landscape. In K. Fryirs, G. J., Brierley, Geomorphic analysis of river systems (pp. 1-8). Chichester: Wiley-Blackwell.

Gábris, Gy., Telbisz, T., Nagy, B., Belardinelli, E. (2002). Accumulation of the floodplain of the Tisza and its geomorphological background. Vízügyi Közlemények, 84, 305-318. [in Hungarian]

Gomez, B., Phillips, D., Magilligan, F.J., James, L.A. (1997). Floodplain sedimentation and sensitivity: Summer 1993 flood, Upper Mississippi Valley. Earth Surface Processes and Landforms, 22, 923-936. https://doi.org/10.1002/(sici)1096-9837(199710)22:10<923::aid-esp763>3.0.co;2-e 
Gregory, K.J. (2004). Human activity transforming and designing river landscapes: A review perspective. Geographia Polonica, 77(2), 5-20.

Happ, S., Rittenhouse, G., Dobson, G. (1940). Some principles of accelerated stream and valley sedimentation. Technical Bulletin, 695, US Department of Agriculture.

Hudson, P.F., Heitmuller, F.T. (2003). Local and watershed-scale controls on the spatial variability of natural levee deposits in a large fine-grained floodplain: lower Pánuco Basin, Mexico. Geomorphology, 56, 255-269. https://doi.org/10.1016/s0169-555x(03)00155-7

Ihrig, D. (1973). History of the river regulations in Hungary. Budapest: Országos Vízügyi Hivatal. [in Hungarian]

Keen-Zebert, A., Tooth, S., Rodnight, H., Duller, G.A.T., Roberts, H.M., Grenfell, M. (2013). Late Quaternary floodplain reworking and the preservation of alluvial sedimentary archives in unconfined and confined valleys in the eastern interior of South Africa. Geomorphology, 185, 54-66.

https://doi.org/10.1016/j.geomorph.2012.12.004

Kiss, T. (2014). Alterations of fluvial processes due to anthropogenic impacts: Study on Equilibrium and sensitivity in fluvial environment. University of Szeged, Hungary. (Doctoral dissertation, in Hungarian)

Kiss, T., Balogh, M., Fiala, K., Sipos, Gy. (2018). Morphology of fluvial levee series along a river under human influence, Maros River, Hungary. Geomorphology, 303, 309-321.

https://doi.org/10.1016/j.geomorph.2017.12.014

Kiss, T., Blanka, V. (2012). River channel response to climate- and human-induced hydrological changes: Case study on the meandering Hernád River, Hungary. Geomorphology, 175-176, 115-125. https://doi.org/10.1016/j.geomorph.2012.07.003

Kiss, T., Nagy, Z., Balogh, M. (2017). Floodplain level development induced by human activity - case study in the Lower Maros/Mures River, Romania and Hungary. Carpathian Journal of Earth and Environmental Sciences, 12 (1), 83-93.

Kiss, T., Oroszi, V.G., Sipos, G., Fiala, K., Benyhe, B. (2011). Accelerated overbank accumulation after nineteenth century river regulation works: A case study on the Maros River, Hungary. Geomorphology 135, 191-202. https://doi.org/10.1016/j.geomorph.2011.08.017

Kiss, T., Sándor, A., Gresó, Zs. (2004). Investigations on the rate of floodplain sediment accumulation in the Mártély embayment of the Lower Tisza. Acta Universitatis Szegediensis Acta Geographica, 38, 15-26.

Klasz, G., Reckendorfer, W., Gabriel, H., Baumgartner, C., Schmalfuss, R., Gutknecht, D. (2014). Natural levee formation along a large and regulated river: The Danube in the National Park Donau-Auen, Austria. Geomorphology, 215, 20-33. https://doi.org/10.1016/j.geomorph.2013.12.023

Laczay, I. (1975). River system of the Maros. In Vízrajzi Atlasz, 19 (pp. 4-23). Budapest: VITUKI. [in Hungarian]

Lane, S.N., Westaway, R.M., Hicks, D.M. (2003). Estimation of erosion and deposition volumes in a large gravel-bed, braided river using synoptic remote sensing. Earth Surface Processes and Landforms 28, 249-271. https://doi.org/10.1002/esp.483

Lóczy, D. (2013). Geomorphological classifications of floodplains in international scientific papers. Földrajzi Közlemények, 137, 105-120. (in Hungarian)

Łajczak, A., Plit, J., Soja, R., Starkel, L., Warowna, J. (2006). Changes of the Vistula River channel and floodplain in the last 200 Years. Geographia Polonica 79(2), 65-88.

Nanson, G.C. (1986). Episodes of vertical accretion and catastrophic stripping: A model of disequilibrium flood-plain development. Geological Society of America Bulletin, 97, 1467-1475. https://doi.org/10.1130/0016-7606(1986)97<1467:eovaac>2.0.co;2

Nanson, G.C., Croke, J.C. (1992). A genetic classification of floodplains. Geomorphology, 4, 459-486. https://doi.org/10.1016/0169-555x(92)90039-q 
Notebaert, B., Verstraeten, G., Govers, G., Poesen, J. (2009). Qualitative and quantitative applications of LiDAR imagery in fluvial geomorphology. Earth Surface Processes and Landforms, 34, 217-231. https://doi.org/10.1002/esp.1705

Radecki-Pawlik, A., Wyżga, B., Czech, W., Mikuś, P., Zawiejska, J., \& Ruiz-Villanueva, V. (2016). Modelling hydraulic parameters of flood flows for a Polish Carpathian river subjected to variable human impacts. In Kundzewicz Z., Stoffel M., Niedźwiedź T., Wyżga B. (Eds.), Flood Risk in the Upper Vistula Basin. GeoPlanet: Earth and Planetary Sciences. Springer, Cham GeoPlanet: Earth and Planetary Sciences (pp. 127-151). Cham: Springer. https://doi.org/10.1007/978-3-319-41923-7_7

Sagar, S.D. (2013). Improved Floodplain Delineation Method Using High-Density LiDAR Data. ComputerAided Civil and Infrastructure Engineering, 28(1), 68-79. https://doi.org/10.1111/j.1467-8667.2012.00774.x

Sándor, A. (2011). Review on the process of floodplain accumulation: case study on the Middle-and Lower-Tisza. (PhD dissertation), Szeged: SZTE. [in Hungarian]

Schweitzer, F., Nagy, I., Alföldi, L. (2002). Recent point-bar formation and floodplain accumulation on the Middle-Tisza. Földrajzi Értesitö, 51(3-4), 257-278. [in Hungarian]

Sipos, Gy. (2006). Review on the dynamic of the riverbed: case study on the Hungarian section of the River Maros. (PhD dissertation), Szeged: SZTE. (in Hungarian)

Sipos, Gy., Kiss, T., Fiala, K. (2007). Morphological alterations due to channelization along the Lower Tisza and Maros Rivers (Hungary). Geografia Fisica e Dinamica Quarternaria, 30, 239-247.

Smith, N.D., Cross, T.A., Dufficy, J.P., Clough, S.R. (1989). Anatomy of an avulsion. Sedimentology, 36, 1-23.

Smith, N.D., Pérez-Arlucea, M. (2008). Natural levee deposition during the 2005 flood of the Saskatchewan River. Geomorphology, 101, 583-594. https://doi.org/10.1016/j.geomorph.2008.02.009

Sorrells, R.M. (2012). Hydrogeomorphology of alluvial benches in an anabranching reach of the upper Yadkin River, North Carolina. (PhD dissertation), Greensboro: University of North Carolina.

Steiger, J., Tabacchi, E., Dufour, S., Corenblit, D., Peiry, J.L. (2005). Hydrogeomorphic processes affecting riparian habitat within alluvial channel-floodplain river systems: A review for the temperate zone. River Research and Applications, 21, 719-737. https://doi.org/10.1002/rra.879

Taylor, C. (2002). Recognising channel and floodplain forms. Water \& Rivers Commision, Report No. RR17. Perth, Australia.

Urdea, P., Sipos, Gy., Kiss, T., Onaca, A. (2012). River Maros. In Sipos, Gy. (Ed.), A Maros folyó múltja, jelene, jövője (pp. 9-32). Szeged: SZTE.

Wierzbicki, G., Ostrowski, P., Mazgajski, M., Bujakowski, F. (2013). Using VHR multispectral remote sensing and LIDAR data to determine the geomorphological effects of overbank flow on a floodplain (the Vistula River, Poland). Geomorphology, 183, 73-81. https://doi.org/10.1016/j.geomorph.2012.06.020

Wolfert, H.P., Hommel, P.W.F.M., Prins, A.H., Stam, M.H. (2002). The formation of natural levees as a disturbance process significant to the conservation of riverine pastures. Landscape Ecology, 17(1), 47-57. https://doi.org/10.1023/A:1015229710294

Wolman, M.G., Leopold, L.B. (1957). River floodplains: Some observations on their formation. USGS Professional Papers, 282C, 87-107.

Zwoliński, Z. (1992). Sedimentology and geomorphology of overbank flows on meandering river floodplains. Geomorphology, 4(6), 367-379. https://doi.org/10.1016/0169-555X(92)90032-J 